Crop Breeding and Applied Biotechnology 14: 1-7 2014

Brazilian Society of Plant Breeding. Printed in Brazil

\title{
ARTICLE
}

\section{Rapid screening for selection of heavy metal-tolerant plants}

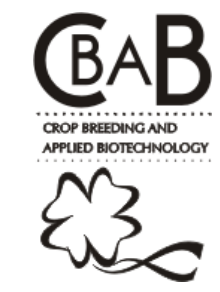

Fernando Angelo Piotto ${ }^{1}$, Augusto Tulmann-Neto ${ }^{2}$, Mônica Regina Franco ${ }^{1}$, Luis Felipe Boaretto ${ }^{1}$ and Ricardo Antunes Azevedo $^{1^{*}}$

Received 07 September 2012

Accepted 26 November 2013

\begin{abstract}
One of the major difficulties in studies on the selection of heavy metal tolerant plants is the proper methodology that must ensure an efficient evaluation of a large number of plants, but reducing environmental contamination. For this reason, we propose a simple and effective method that can be applied to metals or other chemicals by means of a case study, in which we selected two cadmium-tolerant mutants of tomato (cv Micro-Tom) obtained by mutagenesis with methyl ethanesulfonate (MES). Aside from these two new mutants, we selected 21 others with possible alterations in the response to this metal. Finally, it was concluded that the proposed system is ideal for selection studies on plants tolerant to heavy metals and possibly to other elements, due to the ease of assembly of the structure, low installation cost, minimal waste generation and the possibility of using different species and heavy metals.
\end{abstract}

Key words: Mutagenesis, cadmium, tolerance, hydroponics, oxidative stress.

\section{INTRODUCTION}

Mutagenesis has been widely used to generate new alleles, with different goals. Research on mutagenesis is focused largely on the establishment of mutants with alterations for a potential use in plant breeding or which are important for the study of a gene function, causing mutations that can lead to the gain or loss of the function of certain genes (Azevedo et al. 1990, Brennecke et al. 1996, Gaziola et al. 1999, Azevedo et al. 2003, Azevedo et al. 2004a, 2004b). There are several classical methods of mutagenesis using physical agents such as $\gamma$-rays, $x$ -rays and fast neutrons, or chemical agents, e.g., methyl ethanesulfonate (MES), methyl methanesulfonate (MMS), diethyl sulfate (DES), and nitrosoguanidine (NTG, NG, MNNG), among others, which have been successfully used to obtain mutant plants tolerant to biotic (Pathirana 1992, Adu-Ampomah et al. 1996, Bhagwat 1998, Jansen and Schaffrath 2009) and to abiotic stresses (Nawrot et al. 2001, Zhu 2003, Saleem 2005, Tsyganov et al. 2007, Lang and Buu 2008, Koch et al. 2010, Kumar et al. 2010). Thus, mutagenesis is a very important tool to generate plants with genetic alterations that allow a more detailed understanding of the tolerance and sensitivity mechanisms to various stress types.
Addressing the stresses that can affect plants, such as drought and salinity, among others, a constantly increasing number of studies is focused on the abiotic stresses caused by heavy metals, e.g., aluminum ( $\mathrm{Al})$, lead $(\mathrm{Pb})$, and cadmium (Cd), which are associated with the growing problems of soil contamination on a global scale (Gratão et al. 2008, Azevedo et al. 2012).

One of the main approaches to understand the responses of plants to heavy metals is the use of mutants with alterations in sensitivity or tolerance to the metals. Some mutagenesis studies successfully obtained mutants of Cd-hypersensitive Arabidopsis thaliana, through which the role of phytochelatin synthase (Howden et al. 1995, Ha et al. 1999) and $\gamma$-glutamylcysteine synthetase (Cobbett et al. 1998) in the detoxification of this metal could be better understood. However, few mutagenesis studies have addressed the development of heavy metal tolerant plants, and most of them deal with aluminum tolerance in model plants such as $A$. thaliana (Gabrielson et al. 2006) or in cultivated plants of great economic importance such as wheat (Tulmann-Neto et al. 2001) and barley (Nawrot et al. 2001), or in specific cases, for example, with the breeding of Cd-tolerant pea plants (Tsyganov et al. 2007).

Among the barriers to the breeding of heavy metal tol-

\footnotetext{
${ }^{1}$ Universidade de São Paulo, Escola Superior de Agricultura "Luiz de Queiroz", Departamento de Genética,. C. P. 83, 13.418-900, Piracicaba, SP, Brazil. *E-mail: raa@, usp.br

${ }^{2}$ Universidade de São Paulo, Centro de Energia Nuclear na Agricultura, C. P. 96, 13.400-970, Piracicaba, SP, Brazil
} 
erant plants is the proper selection methodology of these individuals. The main problems are related to the difficulty of evaluating a large number of plants under uniform conditions while keeping the amount of environmental residues low. One of the classic ways to select tolerant plants would be to use heavy metal-contaminated land for plant cultivation and evaluation. However, in this case, a regular distribution and homogeneity cannot be ensured nor the metal concentration for which tolerant mutants are to be selected. Another possibility would be to contaminate soil or sand and grow plants in a greenhouse under controlled conditions. On the other hand, mutagenesis studies require the evaluation of a high number of plants, making this option impractical. Besides, there is the additional challenge of the large amount of waste, as these soils can generally not be decontaminated, requiring an adequate structure for an appropriate disposal of the material, although the alternative of bioremediation/ phytoremediation may be an option (Martins et al. 2011, Souza et al. 2013).

As an alternative to soil, sand or substrate, plants can be grown in nutrient solution. In these so-called hydroponic systems, different crops are being successfully produced on a commercial scale, under highly homogeneous and controlled cultivation conditions. There are several studies with heavy metals, using hydroponic systems for the evaluation of responses to, for example, metal accumulation in the plant tissues (Pereira et al. 2002, Fourcaud et al. 2008, Zhang et al. 2009), responses to enzymes linked to the antioxidant system (Ferreira et al. 2002, Gonçalves et al. 2009, López-Millán et al. 2009, Gratão et al. 2012), interactions with macronutrients (Gonçalves et al. 2009), and of toxic effects on plants (Benavides et al. 2005, López-Millán et al. 2009). Furthermore, cultivation in a hydroponic system has the advantage of generating less waste, since the contaminated nutrient solution can be evaporated, reducing the final metal residue to few milligrams. For these reasons, some authors have proposed different methods for selecting Al-tolerant barley (Ma et al. 1997, Hossain et al. 2005, Tamás et al. 2006) and maize plants (Giaveno and Miranda Filho 2000), grown in nutrient solution. These systems can serve as a model methodology for the selection of new mutants with altered responses to heavy metals in different crops.

In this paper, we propose a methodology for the evaluation and selection of heavy metal tolerant plants that has the advantage of combining the benefits of growing plants in nutrient solution with the possibility of evaluating high numbers of plants under metal-induced stress. For this purpose, we present a case study of selection for tolerance to the heavy metal cadmium, in plants of the tomato cultivar Micro-Tom (Solanum lycopersicum L.), widely used as model plant (Meissner et al. 1997) in numerous studies on genetics (Lima et al. 2004, Butelli et al. 2008), physiology (Carvalho et al. 2011, Monteiro et al. 2011, Carvalho et al. 2013), biochemistry of plants (Gratão et al. 2008, Gratão et al. 2012), and on ultrastructural changes (Vitória et al. 2003, Gratão et al. 2009). This tomato cultivar has several advantages, such as a low plant height (about $15 \mathrm{~cm}$ ) and a short life cycle (80-90 days from sowing to harvest), making it a very suitable model plant for mutagenesis studies aimed at selecting new mutants (Matsukura et al. 2007, Watanabe et al. 2007, Pino-Nunes et al. 2009). We believe that the methodology proposed here is fast and effective due to the fact that selection occurs in the seedling stage, few days after germination, allowing the evaluation of a large number of plants per area unit.

\section{MATERIAL AND METHODS}

\section{Mutagenesis}

Using the mutagen MES (methyl ethanesulfonate), according to the protocol adapted by Pino-Nunes et al. (2009), 11,500 seeds of cv Micro-Tom (MT) were mutagenized. The seeds were previously soaked in distilled water for 8 $\mathrm{h}$ and then immersed in the solutions containing MES at a concentration of $0.5 \%$ (Sigma-Aldrich, St. Louis) and maintained under slight agitation for laminar flow $12 \mathrm{~h}$ at room temperature $\left(26 \pm 2{ }^{\circ} \mathrm{C}\right)$. After this treatment, the material was sown immediately, resulting in 7,820 plants of generation M1, of which nearly 6,180 proved fertile. The seeds were harvested from individual plants and grouped in seed lots with $12 \mathrm{M} 2$ progenies each, which were used for the selection of mutants.

\section{Experiment}

For this evaluation and selection method, trays (length 55 , width 35 , height $8 \mathrm{~cm}$ or similar size) were filled with nutrient solution for plant growth and covered with black plastic to avoid light entry. Each tray was covered with a $4 \mathrm{~mm}$-thick styrofoam sheet, with one aluminized side to help prevent light entry. This material is very light, flexible and can be cut to any size. The advantage of styrofoam is that it floats on water and, for being a soft material, small cuts can be made on its edges, which hold the stems of the seedlings (diameter $<5 \mathrm{~mm}$ ) (Figure 1). To optimize the use of space, the styrofoam sheet was cut into pieces (length 350 , width $50 \mathrm{~mm})$, and small cuts $(15 \mathrm{~mm})$ were made on both sides, spaced $25 \mathrm{~mm}$ apart, to support the seedlings. Thus, per tray, each piece of this material had a capacity of 24 seedlings, totaling 264 plants, of which 24 spaces were occupied by non-mutant controls and 240 were used for the plants from mutagenesis M2. Initially, the seeds were germinated in vermiculite and irrigated with nutrient solution proposed by Hoagland and Arnon (1950), adapted for 


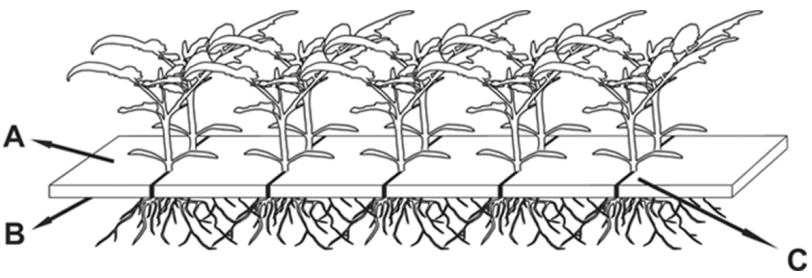

Figure 1. System of a floating styrofoam support for seedling cultivation in nutrient solution. This material can be cut into any shape according to the tray. In general, a styrofoam board (thickness $4 \mathrm{~mm}$ ) is sufficient to support the seedlings and keep the system fluctuating. A) surface with a light and opaque color (reflecting materials could induce stress by light excess), B) Al-covered underside preventing light entry, and C) small lateral cuts to hold seedlings, separating the roots in the dark in contact with the solution underneath from the freely developing shoots above the styrofoam.

tomato, until the expansion of the first true leaf (15 days after germination).

For transplanting, the roots were carefully washed and each seedling was inserted in one of the cuts in the styrofoam sheet. Since this cultivation system is static, the nutrient solution had to be oxygenated with plastic hoses coupled to an air compressor. To make oxygenation more efficient, small porous stones, as commonly used in aquariums, were inserted in the air outlet of the oxygenation hoses, greatly increasing the contact surface of air with the solution, by reducing the size of the bubbles. Furthermore, this kind of oxygenation resulted in a constant agitation of the solution, ensuring the regular distribution of salts in the tray and later of the metal itself that was added to it.

\section{Selection procedure}

Initially, the seedlings were placed in a hydroponic system containing $25 \%$ of the total amount of Hoagland and Arnon (1950) salt solution adapted to tomato ( $\mathrm{pH}$ adjusted to 6.0), to avoid plant stress due to high salt concentrations. The adaptation period was 7 days, after which the solution was exchanged and the salt concentration doubled. The new solution contained $25 \mu \mathrm{M} \mathrm{CdCl}_{2}$ which is the rate that reduces seedling growth at this stage by $50 \%$, as found in preliminary experiments. After 4 to 5 days, symptoms of $\mathrm{Cd}$ toxicity appear on the seedlings at this stage, from which plantlets without the typical symptoms of metal toxicity can be initially selected. These selected plants were removed from the system and placed in another tray containing nutrient solution without heavy metal, to let the plants complete the reproductive cycle and produce M3 seeds for progeny tests that would confirm the tolerance of the new mutants.

\section{RESULTS AND DISCUSSION}

In this case study with cultivar MT, 11,500 mutagenized seeds were initially selected in search of Cd-tolerant mutants
(Table 1). Around 10,000 seedlings of the M2 generation were obtained from a total of 12,000 seeds sown initially, of which approximately 2,000 were lost, due to the occurrence of deleterious mutations. Thus, we reached a total of approximately 10,000 seedlings evaluated on $16 \mathrm{~m}^{2}$. Of this total, 28 potentially Cd-tolerant plants were selected. Usually, most mutant plants have some degree of infertility and for this reason, five potentially tolerant plants produced no seeds, leaving $23 \mathrm{M} 3$ progenies for further evaluation of tolerance. One of these progenies had a satisfactory degree of $\mathrm{Cd}$ tolerance and was provisionally named progeny $\mathrm{Cd} 23$ ( $23^{\text {rd }}$ selected mutant), with no apparent $\mathrm{Cd}$ toxicity symptoms until 10 days after exposure to the metal (Figure 2), when compared to the wild type control (cv Micro-Tom). Fifteen days after $\mathrm{Cd}$ exposure, some mild symptoms appeared on these progeny plants, which were then removed from the nutrient solution and transplanted to the commercial substrate, to produce M4 generation seeds for further testing.

Table 1. Number of plants obtained at each stage of selection of Cdtolerant mutants

\begin{tabular}{ll}
\hline Stages of the selection process & Total \\
\hline Mutagenized seeds & 11.500 \\
M1 plants & 7.820 \\
Fertile M2 plants & 6.180 \\
Seed lots of 12 M2 progenies & 503 \\
Evaluated M2 progenies & 1.200 \\
Approximate total of evaluated M2 plants & 10.000 \\
M2 plants selected as potentially tolerant & 28 \\
Selected infertile plants & 5 \\
M3 progenies evaluated to confirm tolerance & 23 \\
Tolerant M4 progenies selected for assessment & 1 \\
Other selected mutants & 4 \\
\hline
\end{tabular}

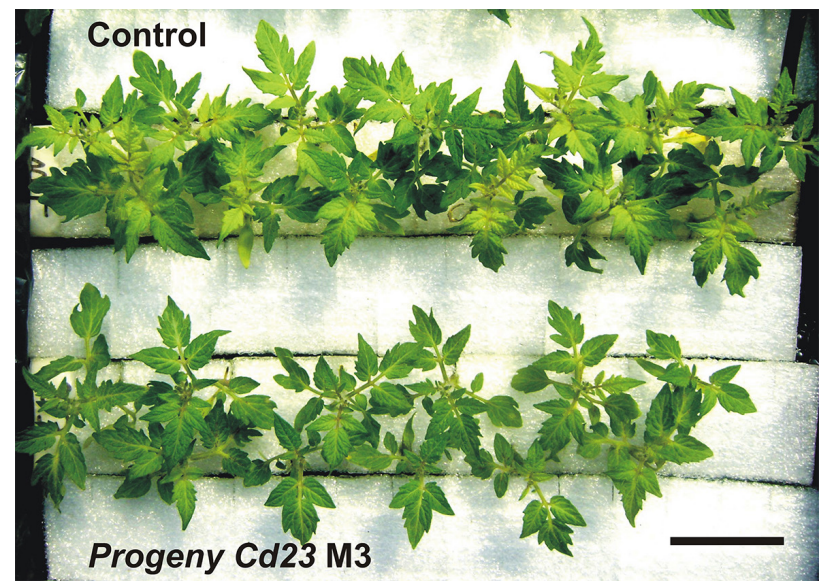

Figure 2. Plants of $C d 23 \mathrm{M} 3$ (lower row) with few or no toxicity symptoms to $25 \mu \mathrm{M} \mathrm{CdCl}_{2}$, compared with the wild type control plants (upper row), with chlorosis symptoms on young leaves. Bar $=50 \mathrm{~mm}$. 
Aside from the Cd-tolerant mutants, other plants with changes in leaf architecture, chlorophyll content, reduction in the number of flowers and reduced size were selected (Table 1), similar to what was observed by Matsukura et al. (2007), Watanabe et al. (2007) and Pìno-Nunes et al. (2009) in mutagenesis studies with cv. MT. The appearance of these other mutations confirmed the efficiency of the applied mutagenesis procedure. However, other mutations were not eliminated by the selection system, which is still a common fact in all mutagenesis and selection procedures, despite the maximized efficiency and restrictiveness of the selection process (Azevedo and Arruda 1995). Therefore, the vigor of development of the $C d 23$ mutant plants was not the same as of the non-mutant plants, and a genetic cleaning process by means of backcrosses was required to eliminate the probable genetic load acquired by the mutagenesis process. If on the one hand other mutations were found in addition to the expected mutation (Cd tolerant), it is evident that this system also allows the identification of other mutations that may possibly be of some interest. The selected genotypes (Cd-tolerant and others) can also be tested for tolerance to other toxic elements and stress types, since the observed Cd-tolerance response may reflect an overall greater tolerance level, not specifically restricted to this metal. These aspects are being analyzed by our group, because once a mutant tolerant to $\mathrm{Cd}$ or to another other metal is identified, follow-up studies are needed to understand the tolerance mechanisms of the selected mutants.

The mutation (or set of mutations) that determines $\mathrm{Cd}$ tolerance may be linked to several different mechanisms of action, altering single or combined physiological, genetic and biochemical processes. In general, the main factors that increase the tolerance of a plant are associated with its ability to exclude toxic ions and limit their distribution to the more sensitive tissues, reducing their translocation to the shoot (Verbruggen et al. 2009), metal deposition on cell walls (Vazquez et al. 2006), chelate formation with organic molecules (phytochelatins, metallothionein, glutathione, etc.), and the subsequent compartmentalization of these complexes in the vacuoles (Benavides et al. 2005, Gratão et al. 2005, Gallego et al. 2012). Other tolerance mechanisms can also result from the process of mutagenesis, such as an increase in the efficiency of nutrient uptake and assimilation, for example of sulfur (S), making these plants more Cd-tolerant (Gill and Tuteja 2010). It is also possible that mutations can lead to changes in the enzymatic antioxidant system by increasing the activity of enzymes involved in the control of reactive oxygen species (ROS) in cells, which can cause the so-called oxidative stress when in excess (Azevedo et al. 1998, Gratão et al. 2005, Dourado et al. 2013). For instance, it has been shown that more Cd-tolerant potato cultivars have increased activity of catalase (CAT), which is one of the key enzymes in the elimination of hydrogen peroxide, a ROS that can cause severe cell damage (Gratão et al. 2005).

On the one hand, heavy metal tolerance has been the main target of several studies, while there is also an increasing interest in research to breed plants that are not only tolerant, but can also hyperaccumulate heavy metals in their tissues, making them potentially useful for the phytoremediation of contaminated soils (Pilon-Smits 2005, Souza et al. 2013). On the other hand, the development of hyperaccumulating plants through mutagenesis or by exploiting the genetic resources available, is important not only for phytoextraction of metals from the soil but they could also be applied as a strategy for food biofortification (Palmgren et al. 2008), where the hyperaccumulated metal would be an essential nutrient for human consumption.

Finally, the breeding of more tolerant and/or metalaccumulating plants would be the first stage of many theoretical and applied studies on abiotic stress tolerance caused by heavy metals in the soil, phytoremediation, or on biofortification, among others. In this context, the cultivation and selection system of Cd tolerant plants proposed in this paper allows the cultivation of a large number of plants per area unit, if selection is performed in the early growth stages of each species. It can also be used efficiently for the cultivation and selection of heavy metal tolerant seedlings of other species such as rice, wheat, barley, rye, and peppers, which can be inserted in the styrofoam sheet. For this, it would only be necessary to adjust: 1) the nutrient solution and $\mathrm{pH}$ adequately for the growth of each species, 2) the spacing in which the seedlings will be grown, 3) the heavy metal concentrations that cause symptoms in seedlings at a certain stage of evaluation, and 4) the characteristic toxicity symptoms of each metal on the study species as well as the exposure time until they appear. This system minimizes the amount of waste generated by simply letting the nutrient solution dry to collect the residual metals and precipitated salts. Finally, we conclude that the system of cultivation and selection used in this work was satisfactory to identify and select $\mathrm{Cd}$ tolerant tomato plants. Thus, we propose the use of this methodology for the evaluation and selection of plants of various species, tolerant to different heavy metals and other chemicals.

\section{ACKNOWLEDGEMENTS}

The authors are indebted to the institutions National Council for Scientific and Technological Development CNPq, Brazilian Federal Agency for Support and Evaluation of Graduate Education - CAPES and State of São Paulo Research Foundation - FAPESP (Grant no. 2009/54676-0) for funding this work. 


\section{Rápida avaliação para seleção de plantas tolerantes a metais pesados}

Resumo - Uma das principais dificuldades nos trabalhos visando a seleção de plantas tolerantes a metais pesados é a própria metodologia para avaliação eficiente de grande número de plantas, gerando poucos resíduos para o meio ambiente. Por esse motivo, propomos uma metodologia simples e eficaz que pode ser aplicada a metais ou outros elementos químicos, partindo de um estudo de caso, no qual selecionamos dois mutantes de tomateiro (cv Micro-Tom) tolerantes ao Cádmio, obtidos por mutagênese com etanosulfonato de metila (EMS). Além destes dois novos mutantes, selecionamos outros 21 com alterações potenciais quanto a respostas a este metal. Por fim, chegamos à conclusão de que o sistema proposto é ideal para trabalhos de seleção de plantas tolerantes a metais pesados e possivelmente a outros elementos, devido à facilidade de montagem da estrutura, baixo custo de implantação, minimização de geração de resíduos e possibilidade de uso em várias espécies e diferentes metais pesados.

Palavras-chave: Mutagênese, cádmio, tolerância, hidropônico, estresse oxidativo.

\section{REFERENCES}

Adu-Ampomah Y, Owusu GK, Sackey S, Padi B and Abdul-Karimu A (1996) Use of gamma rays to induce mutants resistant to cocoa swollen shoot disease in Theobroma cacao L. Plant Breeding 115: 74-76.

Azevedo RA, Alas RJ, Smith RJ and Lea PJ (1998) Response of antioxidant enzymes to transfer from elevated carbon dioxide to air and ozone fumigation, in the leaves and roots of wild-type and a catalasedeficient mutant of barley. Physiologia Plantarum 104: 280-292.

Azevedo RA, Arana JL and Arruda P (1990) Biochemical genetics of the interaction of the lysine plus threonine resistant mutant Ltr*1 with opaque-2 maize mutant. Plant Science 70: 81-90.

Azevedo RA and Arruda P (1995) Dominant and recessive mutations conferring resistance to S-2-aminoethyl-L-cysteine in maize. Journal of Plant Physiology 145: 321-326.

Azevedo RA, Damerval C, Landry J, Lea PJ, Bellato CM, Meinhardt LW, Guilloux ML, Delhaye S, Toro AA, Gaziola SA and Berdejo BDA (2003) Regulation of maize lysine metabolism and endosperm protein synthesis by opaque and floury mutations. European Journal of Biochemistry 270: 4898-4908.

Azevedo RA, Damerval C, Lea PJ, Landry J, Bellato CM, Meinhardt LW, Guilloux ML, Delhaye S, Toro AA, Gaziola SA, Varisi VA and Gratão PL (2004a) Genetic control of lysine metabolism in maize endosperm mutants. Functional Plant Biology 31: 339-348.

Azevedo RA, Gratão PL, Monteiro CC and Carvalho RF (2012) What is new in the research on cadmium-induced stress in plants? Food and Energy Security 1: 133-140.

Azevedo RA, Lea PJ, Damerval C, Landry J, Bellato CM, Meinhardt LW, Guilloux ML, Delhaye S, Varisi VA, Gaziola SA, Gratão PL and Toro AA (2004b) Regulation of lysine metabolism and endosperm protein synthesis by the opaque-5 and opaque-7 maize mutations. Journal of Agricultural and Food Chemistry 52: 4865-4871.

Benavides MP, Gallego SM and Tomaro ML (2005) Cadmium toxicity in plants. Brazilian Journal of Plant Physiology 17: 21-34.

Bhagwat B (1998) Mutation breeding of banana cv. Highgate (Musa spp., AAA Group) for tolerance to Fusarium oxysporum f. sp. cubense using chemical mutagens. Scientia Horticulturae 73: 11-22.

Brennecke K, Neto AJS, Lugli J, Lea PJ and Azevedo RA (1996)
Aspartate kinase in the maize mutants ASK1-LT19 and OPAQUE-2. Phytochemistry 41: 707-712.

Butelli E, Titta L, Giorgio M, Mock HP, Matros A, Peterek S, Schijlen EGWM, Hall RD, Bovy AG, Luo J and Martin C (2008) Enrichment of tomato fruit with health-promoting anthocyanins by expression of select transcription factors. Nature Biotechnology 26: 1301-1308.

Carvalho RF, Aidar ST, Azevedo RA, Dodd IC and Peres LEP (2011) Enhanced transpiration rate in the high pigment 1 tomato mutant and its physiological significance. Plant Biology 13: 546-550.

Carvalho RF, Monteiro CC, Caetano AC, Dourado MN, Gratão PL, Haddad CRB, Peres LEP and Azevedo RA (2013) Leaf senescence in tomato mutants as affected by irradiance and phytohormones. Biologia Plantarum 57: 749-757.

Cia MC, Guimarães ACR, Medici LO, Chabregas SM and Azevedo RA (2012) Antioxidant responses to water deficit by drought-tolerant and -sensitive sugarcane varieties. Annals of Applied Biology 161: 313-324.

Cobbett CS, May MJ, Howden R and Rolls B (1998) The glutathionedeficiente, cadmium-sensitive cad2-1, of Arabidopsis thaliana is deficient in $\gamma$-glutamylcysteine synthetase. The Plant Journal 16: 73-78.

Dourado MN, Martins PF, Quecine MC, Piotto FA, Souza LA, Franco MR, Tezotto T and Azevedo RA (2013) Burkholderia sp. SCMS54 reduces cadmium toxicity and promotes growth in tomato. Annals of Applied Biology doi:10.1111/aab.12066 (in press).

Ferreira RR, Fornazier RF, Vitória AP, Lea P and Azevedo RA (2002) Changes in antioxidant enzyme activities in soybean under cadmium stress. Journal of Plant Nutrition 25: 327-342.

Fourcaud T, Zhang X, Stokes A, Lambers H and Körner C (2008) Plant growth modelling and applications: the increasing importance of plant architecture in growth models. Annals of Botany 101: 1053-1063.

Gabrielson KM, Cancel JD, Morua LF and Larsen PB (2006) Identification of dominant mutations that confer increased aluminium tolerance through mutagenesis of the Al-sensitive Arabidopsis mutant, als3-1. Journal of Experimental Botany 57: 943-951.

Gallego SM, Pena LB, Barcia RA, Azpilicueta CE, Iannone MF, Rosales EP, Zawoznik MS, Groppa MD and Benavides MP (2012) Unravelling cadmium toxicity and tolerance in plants: Insight into regulatory 
mechanisms. Environmental and Experimental Botany 83: 33-46.

Gaziola SA, Alessi ES, Guimarães PEO, Damerval C and Azevedo RA (1999) Quality protein maize: A biochemical study of enzymes involved in lysine metabolism. Journal of Agricultural and Food Chemistry 47: 1268-1275.

Giaveno CD and Miranda Filho JB (2000) Rapid screening for aluminum tolerance in maize (Zea mays L.). Genetics and Molecular Biology 23: $847-850$.

Gill SS and Tuteja N (2010) Reactive oxygen species and antioxidant machinery in abiotic stress tolerance in crop plants. Plant Physiology and Biochemistry 48: 909-930.

Gonçalves JF, Antes FG, Maldaner J, Pereira LB, Tabaldi LA, Rauber R, Rossato LV, Bisognin DA, Dressler VL, Flores EMDM and Nicoloso FT (2009) Cadmium and mineral nutrient accumulation in potato plantlets grown under cadmium stress in two different experimental culture conditions. Plant Physiology and Biochemistry 47: 814-821.

Gratão PL, Monteiro CC, Carvalho RF, Tezotto T, Piotto FA, Peres LEP and Azevedo RA (2012) Biochemical dissection of diageotropica and Never ripe tomato mutants to Cd-stressful conditions. Plant Physiology and Biochemistry 56: 79-96.

Gratão PL, Monteiro CC, Peres LEP and Azevedo RA(2008) The isolation of antioxidant enzymes from mature tomato (cv. Micro-Tom) plants. HortScience 43: 1608-1610.

Gratão PL, Monteiro CC, Rossi ML, Martinelli AP, Peres LEP, Medici LO, Lea PJ and Azevedo RA (2009) Differential ultrastructural changes in tomato hormonal mutants exposed to cadmium. Environmental and Experimental Botany 67: 387-394.

Gratão PL, Polle A, Lea PJ and Azevedo RA (2005) Making the life of heavy metal-stressed plants a little easier. Functional Plant Biology 32: 481-494.

Ha SB, Smith AP, Howden R, Dietrich WM, Bugg S, O'Connell MJ, Goldsbrough PB and Cobbett CS (1999) Phytochelatin synthase genes from Arabidopsis and the yeast Schizosaccharomyces pombe. The Plant Cell 11: 1153-1164.

Hoagland DR and Arnon DI (1950) The water-culture method for growing plants without soil. University of California, 32p. (Circular 347).

Hossain M, Zhou M and Mendham N (2005) A reliable screening system for aluminium tolerance in barley cultivars. Australian Journal of Agricultural Research 56: 475-482.

Howden R, Goldsbrough PB, Andersen CR and Cobbett CS (1995) Cadmium-sensitive, cad1 mutants of Arabidopsis thaliana are phytochelatin deficient. Plant Physiology 107: 1059-1066.

Jansen M and Schaffrath U (2009) The barley mutant emr2 shows enhanced resistance against several fungal leaf pathogens. Plant Breeding 128: $124-129$.

Koch AC, Ramgareeb S, Snyman SJ, Watt MP and Rutherford RS (2010) Pursuing imazapyr herbicide tolerance in sugarcane: Screening plants produced in vitro through somaclonal variation and mutagenesis. South African Journal of Botany 76: 396-396.

Kumar K, Gill M, Kaur H, Choudhary O and Gosal S (2010) In Vitro mutagenesis and somaclonal variation assisted salt tolerance in "rough lemon" (Citrus jambhiri Lush.). European Journal of Horticultural Science 75: 233-238.

Lang N and Buu B (2008) Induction of salt tolerance in high yielding traditional rice cultivars through mutagenesis and somaclonal variation. Sabrao Journal of Breeding and Genetics 40: 141-146.

Lima JE, Carvalho RF, Tulmann-Neto A, Figueira A and Peres LEP (2004) Micro-MsK: a tomato genotype with miniature size, short life cycle, and improved in vitro shoot regeneration. Plant Science 167: 753-757.

López-Millán AF, Sagardoy R, Solanas M, Abadía A and Abadía J (2009) Cadmium toxicity in tomato (Lycopersicon esculentum) plants grown in hydroponics. Environmental and Experimental Botany 65: 376-385.

Ma JF, Zheng SJ, Li XF, Takeda K and Matsumoto H (1997) A rapid hydroponic screening for aluminium tolerance in barley. Plant and Soil: $133-137$.

Martins PF, Carvalho G, Gratão PL, Dourado MN, Pileggi M, Araujo WL and Azevedo RA (2011) Effects of the herbicides acetochlor and metolachlor on antioxidant enzymes in soil bacteria. Process Biochemistry 46: 1186-1195.

Matsukura C, Yamaguchi I, Inamura M, Ban Y, Kobayashi Y, Yin Y-gen, Saito T, Kuwata C, Imanishi S and Nishimura S (2007) Generation of gamma irradiation-induced mutant lines of the miniature tomato (Solanum lycopersicum L.) cultivar 'Micro-Tom'. Plant Biotechnology 24: 39-44.

Meissner R, Jacobson Y, Melamed S, Levyatuv S, Shalev G, Ashri A, Elkind Y and Levy A (1997) A new model system for tomato genetics. The Plant Journal 12: 1465-1472.

Monteiro CC, Carvalho RF, Gratão PL, Carvalho G, Tezotto T, Medici LO, Peres LEP and Azevedo RA (2011) Biochemical responses of the ethylene-insensitive Never ripe tomato mutant subjected to cadmium and sodium stresses. Environmental and Experimental Botany 71: 306-320.

Nawrot M, Szarejko I and Maluszynski M (2001) Barley mutants with increased tolerance to aluminium toxicity. Euphytica 120: 345-356.

Palmgren MG, Clemens S, Williams LE, Krämer U, Borg S, Schjørring JK and Sanders D (2008) Zinc biofortification of cereals: problems and solutions. Trends in Plant Science 13: 464-473.

Pathirana R (1992) Gamma ray-induced field tolerance to Phytophthora blight in sesame. Plant Breeding 108: 314-319.

Pereira GJG, Molina SMG, Lea PJ and Azevedo RA (2002) Activity of antioxidant enzymes in response to cadmium in Crotalaria juncea. Plant and Soil 239: 123-132.

Pilon-Smits E (2005) Phytoremediation. Annual Review of Plant Biology 56: 15-39. 
Pino-Nunes LE, Figueira AVO, Tulmann-Neto A, Zsögön A, Piotto FA, Silva J, Bernardi W and Peres LEP (2009) Induced mutagenesis and natural genetic variation in tomato "Micro-Tom." Acta Horticulturae 821: $63-72$.

Saleem J (2005) Induced mutation and in vitro techniques as a method to induce salt tolerance in Basmati rice (Oryza sativa L.). International Journal of Environmental Science and Technology 2: 141-145.

Souza LA, Piotto FA, Nogueirol RC and Azevedo RA (2013) Use of nonhyperaccumulator plants for heavy metals phytoextraction from soil. Scientia Agricola 70: 296-301.

Tamás L, Budikova S, Simonovicova M, Huttova J, Siroka B and Mistrik I (2006) Rapid and simple method for Al-toxicity analysis in emerging barley roots during germination. Biologia Plantarum 50: 87-93.

Tsyganov VE, Belimov AA, Borisov AY, Safronova VI, Georgi M, Dietz KJ and Tikhonovich IA (2007) A chemically induced new pea (Pisum sativum) mutant SGECdt with increased tolerance to, and accumulation of cadmium. Annals of Botany 99: 227-237.

Tulmann-Neto A, Camargo CEO, Castro JLD and Filho AWPF (2001) Evaluation of "Anahuac" wheat mutant lines for aluminum tolerance.
Euphytica 120: 339-343.

Vázquez S, Goldsbrough P and Carpena RO (2006) Assessing the relative contributions of phytochelatins and the cell wall to cadmium resistance in white lupin. Physiologia Plantarum 128: 487-495.

Verbruggen N, Hermans C and Schat H (2009) Mechanisms to cope with arsenic or cadmium excess in plants. Current Opinion in Plant Biology 12: 364-372.

Vitória AP, Rodriguez APM, Cunha M, Lea PJ and Azevedo RA (2003) Structural changes in radish seedlings exposed to cadmium. Biologia Plantarum 47: 561-568.

Watanabe S, Mizoguchi T, Aoki K, Kubo Y, Mori H, Imanishi S, Yamazaki Y, Shibata D and Ezura H (2007) Ethylmethanesulfonate (EMS) mutagenesis of Solanum lycopersicum cv. Micro-Tom for large-scale mutant screens. Plant Biotechnology 24: 33-38.

Zhang J, Sun W, Li Z, Liang Y and Song A (2009) Cadmium fate and tolerance in rice cultivars. Agronomy for Sustainable Development 29: $483-490$.

Zhu M (2003) Mutation induced enhancement of Al tolerance in barley cell lines. Plant Science 164: 17-23. 